Ethos: Jurnal Penelitian dan Pengabdian kepada Masyarakat, Vol 8, No.2, Juni 2020: 285-291

\title{
Pelatihan Peningkatan Kemampuan Kewirausahaan dan Pembukuan dalam MENDUKUng TERBENTUKNYA WIRAUSAHA BARU DI KABUPATEN INDRAMAYU
}

\author{
${ }^{1}$ Asep Darmansyah, ${ }^{2}$ Umi Zuraida, ${ }^{3}$ Yedi Purwanto \\ 1,2,3 Institut Teknologi Bandung, Bandung, Jawa Barat, Indonesia \\ email: ${ }^{1}$ asep.darmansyah@sbm-itb.ac.id
}

\begin{abstract}
The Entrepreneurship and bookkeeping training aims to increase knowledge, attitudes and skills about entrepreneurship and bookkeeping for prospective new entrepreneurs, so that they know, understand and be able to become resilient entrepreneurs. This activity was carried out in Indramayu Regency, West Java. Young men / women dropping out of school as unemployed productive age, ladies and gentlemen who have the potential to become entrepreneurs, developed their potential and abilities through the concepts of learning, practicing, and working. Through this approach, prospective entrepreneurs can actualize their potential in developing a type of business oriented to local resources that can increase income as well as the economy of the surrounding community. Learning activities involve participant participation through the PRA (participatory rural appraisal) method. Stages of activities consist of preparation, program implementation, training, and monitoring and evaluation of the implementation of activities. The results of the activities show that entrepreneurship training and bookkeeping activities are very closely followed by prospective new entrepreneurs with high enthusiasm, given their desire to gain understanding and facilitation in order to overcome the main problems they face in the field. An increase in the knowledge, understanding and skills of the participants between before training and after training.

Keywords: Training; Entrepreneur; Bookkeeping; Indramayu
\end{abstract}

\begin{abstract}
Abstrak. Pelatihan kewirausahaan dan pembukuan bertujuan untuk meningkatkan pengetahuan, sikap dan keterampilan tentang kewirausahaan dan pembukuan usaha bagi calon wirausaha baru (WUB), agar mereka mengetahui, memahami dan mampu menjadi wirausahawan tangguh. Kegiatan ini dilakukan di Kabupaten Indramayu, Jawa Barat. Para pemuda/pemudi putus sekolah sebagai penganggur usia produktif, bapak-bapak dan ibu-ibu berusia produktif yang berpotensi menjadi wirausaha dikembangkan potensi dan kemampuannya melalui konsep belajar, berlatih, dan bekerja. Melalui pendekatan ini para para calon wirausahawan dapat mengaktualisasikan potensi mereka dalam mengembangkan suatu jenis usaha yang berorientasi pada sumber daya lokal yang dapat meningkatkan pendapatan sekaligus perekonomian masyarakat sekitar. Kegiatan pembelajaran melibatkan partisipasi peserta melalui metode PRA (participatory rural appraisal). Tahapan kegiatan terdiri dari persiapan, pelaksanaan program, pelatihan, dan monitoring evaluasi pelaksanaan kegiatan. Hasil kegiatan menunjukkan bahwa kegiatan pelatihan kewirausahaan dan pembukuan sangat diikuti oleh para calon wirausaha baru dengan semangat yang tinggi, mengingat keinginan mereka untuk mendapatkan pemahaman dan fasilitasi dalam rangka mengatasi permasalahan utama yang dihadapinya di lapangan. Terjadi peningkatan pengetahuan, pemahaman dan keterampilan para peserta antara sebelum pelatihan dengan setelah pelatihan.
\end{abstract}

Kata Kunci: Pelatihan, Wirausaha, Pembukuan, Indramayu 


\section{Pendahuluan}

\section{Latar Belakang}

Pemerintah Provinsi Jawa Barat merintis pencetakan 100.000 wirausaha baru pada berbagai bidang meliputi bidang industri kreatif, perdagangan, jasa kreatif, pertanian dan bidang lainnya. Pencetakan wirausaha baru dilakukan oleh berbagai sektor dan SKPD di Jabar, juga bersinergi dengan perusahaan BUMN maupun swasta. Targetnya adalah 100.000 pengusaha baru untuk mengejar porsi ideal dua persen wirausaha dari seluruh warga Jabar. Kehadiran para pengusaha baru itu berperan penting dalam menciptakan lapangan pekerjaan, mengurangi angka pengangguran, sehingga bisa meningkatkan perekonomian masyarakat Jawa Barat khususnya, dan umumnya perekonomian secara nasional.

Kini rasio jumlah pengusaha di Jabar masih di bawah dua persen, tepatnya di angka 1,3 persen dari total penduduk Jawa Barat. Kegiatan pencetakan wirausaha baru ini sebagai sebuah usaha agar tercipta rasio yang ideal antara pengusaha dan jumlah penduduk. Dalam ilmu ekonomi, harus ada keseimbangan minimal empat persen dari populasi sebuah negara harus ada pengusahanya. Minimnya pengusaha sangat berpengaruh terhadap ketersediaan lapangan pekerjaan akibatnya terjadi pengangguran. Kehadiran pengusaha baru akan memberikan peluang untuk pemenuhan lapangan pekerjaan, selain untuk dirinya juga bagi orang lain (Heryawan, Ahmad, 2015).

Kebutuhan hidup yang tidak bisa ditunda dengan perolehan pendapatan yang rendah menjadikan beban hidup masyarakat menjadi berat (Claudia, dkk., 2019). Kemampuan berinovasi dan daya kreativitas seseorang sangat diperlukan untuk terus bertahan hidup dalam suasana serba keterbatasan. Namun kreatifitas dan inovasi mereka kurang berkembang karena keterbatasan yang ada menyangkut permodalan, wawasan pengetahuan bisnis dan pembukuan. Potensi dan peluang untuk berkembang salah satunya dirasakan oleh para penduduk calon wirausaha di Kabupaten Indramayu. Mereka mempunyai motivasi untuk berwirausaha, memiliki jiwa seni dan keterampilan teknis produksi. Melalui program pencetakan 100.000 wirausaha baru Jawa Barat, para calon pengusaha ini perlu dikembangkan potensi dan kemampuan dirinya untuk belajar dan berlatih bersama, dengan berorientasi pada dunia usaha sehingga menjadi wirausaha baru yang unggul.

Seseorang dikatakan sebagai wirausahawan apabila mempunyai kemampuan melihat dan menilai peluang, mengelola sumber daya yang dibutuhkan serta mengambil tindakan yang tepat, guna memastikan sukses secara berkelanjutan (Pio, 2016). Seorang wirausaha dalam mengelola sumber daya perlu mengetahui secara pasti bagaimana kondisi keuangan usahanya (Rivai, 2013). Melalui laporan keuangan yang baik akan bisa dilihat perkembangan usahanya sehingga dapat mengetahui laporan pengeluaran dan pendapatannya secara pasti. Laporan keuangan ini juga digunakan sebagai bahan bagi pihak eksternal (lembaga keuangan) dalam memutuskan memberikan pinjaman. Oleh karena itu, penyelenggaraan pelatihan kewirausahaan dan pembukuan bagi mereka sangat mendesak untuk dilakukan.

$$
\text { Malcolm Tight (2002), }
$$

menyatakan bahwa pelatihan lebih diasosiasikan pada mempersiapkan seseorang dalam melaksanakan suatu peran atau tugas, biasanya dalam dunia kerja. Pelatihan bisa juga dilihat sebagai elemen khusus atau keluaran dari suatu proses pendidikan yang lebih umum. Pelatihan memiliki ciri-ciri yang khas, 
seperti yang diungkapkan oleh Philips $\mathrm{H}$. Coombs dan Manzoer Ahmed (1993), yang menyatakan bahwa ciri khas pelatihan sebagai suatu pendekatan pembangunan adalah:

1. Diusahakan sedapat mungkin untuk menyesuaikan bahan pengajaran dengan pola budidaya dan keadaan lingkungan di kampung halaman peserta;

2. Seluruh kursus diselenggarakan sesuai dengan suatu siklus penuh untuk budi daya bersangkutan bagian terbanyak dari masa pelajaran untuk kerja praktik;

3. Pelajaran di ruang kelas dititikberatkan pada diskusi dalam kelompok kecil dari pada ceramah. Penyelenggaraan pelatihan hendaknya dilakukan secara sistematis dan berkesinambungan.

Untuk membantu memberdayakan para calon wirausaha di Kabupaten Indramayu dalam memaksimalkan kemampuan mereka dalam berwirausaha dilakukan pendekatan pelatihan, dan pendampingan bisnis. Diharapkan dengan pendekatan ini dapat membantu para pemuda dan pemudi calon wirausaha memaksimalkan potensi mereka dalam mengembangkan suatu jenis usaha yang berorientasi pada sumber daya lokal yang dapat meningkatkan perekonomian masyarakat desa.

Keberhasilan pelatihan sangat dipengaruhi oleh beberapa hal, antara lain antusiasme dan peran aktif peserta dalam pelatihan, serta menyelesaikan semua tugas pelatihan yang diberikan dengan baik (Oktaviani, dkk., 2019). Terkait dengan pelatihan Eddie Davies (2005) mengajukan 10 langkah efektif menyelenggarakan pelatihan, yaitu :

1. Mengidentifikasi kebutuhan pelatihan, yaitu mendeteksi permasalahan yang dihadapi saat ini dan tuntutan masa yang akan datang, khususnya yang dapat diatasi dengan menyelenggarakan pelatihan.

2. Mengklarifikasi sasaran pelatihan, yaitu mengkaji kemampuan yang diharapkan dimiliki oleh peserta setelah mengikuti program.

3. Mempertimbangkan peserta/kelompok sasaran dengan mencoba memahami dan mengidentifikasi kesenjangan calon peserta agar rancangan pelatihan dapat menutup kesenjangan tersebut.

4. Mengembangkan garis besar program pelatihan, yaitu rencana induk yang disusun secara hierarkis dan sekuensial.

5. Memilih metode dan media, yaitu strategi dan perangkat pembelajaran yang aplikatif atau mudah digunakan dan efektif dalam menghantarkan pesan pembelajaran.

6. Menyiapkan panduan bagi pemimpin yang meliputi rencana sesi, handouts dan storyboard.

7. Melakukan uji coba sesi pelatihan, yaitu menerapkan rancangan pada target yang terbatas untuk mendeteksi sedini mungkin hal-hal yang menyebabkan kegagalan pelatihan, misalnya ketepatan waktu, penafsiran yang berbeda, dan lain-lain.

8. Melaksanakan sesi pelatihan, dengan tetap melakukan pemantauan untuk dapat mendeteksi apakah pelaksanaan kegiatan merujuk pada rencana yang telah disusun atau tidak.

9. Melakukan tindak lanjut pelatihan, agar hasil pelatihan dapat diimplementasikan oleh peserta sekembalinya ke tempat kerja. 
10. Mengevaluasi hasil, yaitu mengukur dan menilai apakah setiap tahapan program menggunakan biaya sesuai dengan kebutuhan ? Apakah terjadi perubahan kinerja ke arah yang positif? Apakah biaya yang dikeluarkan sebanding dengan manfaat yang diperoleh ?

\section{Identifikasi Masalah}

Berikut ini adalah permasalahan yang dihadapi penduduk dan calon wirausaha di Kabupaten Indramayu:

1. Sikap mental yang memandang bekerja di kantoran lebih bergengsi sehingga menjadi tujuan utama untuk meraihnya.

2. Sikap mental yang tidak mau menanggung risiko bisnis sehingga motivasi berwirausaha tidak berkembang.

3. Tidak tersedianya sumber permodalan bisnis yang cukup untuk memulai bisnis dan ekspansi bisnis.

4. Belum memiliki pengetahuan berbisnis dan penentuan sasaran usaha pada pengembangan usaha yang prospektif.

5. Lemahnya networking dengan instansi pemerintah atau swasta dan lembaga keuangan karena ketidakmampuan membuat laporan keuangan yang melaporkan kinerja keuangan bisnisnya.

\section{Tujuan Kegiatan Pengabdian Masyarakat}

Tujuan yang ingin dicapai pada kegiatan ini adalah :

1. Meningkatnya pengetahuan kewirausahaan baik dari ranah kognitif, afektif dan psikomotorik para calon wirausaha; 2. Meningkatkan
berwirausaha para $\begin{array}{r}\text { motivasi } \\ \text { calon }\end{array}$ wirausaha; Menentukan jenis usaha perencanaan usaha, pembukuan dan pelaporan keuangan;

\section{Metode}

\section{Metode Pelatihan}

1. Ceramah

Metode ceramah dimaksudkan sebagai bentuk penyampaian materi pelatihan secara lisan, disampaikan dalam garis-garis besar, singkat dan tidak bertele-tele, segar dan menyenangkan.

2. Bermain peran/simulasi

Bermain peran atau simulasi merupakan metode pelatihan dengan membuat kondisi nyata dari keadaan yang terjadi di masyarakat. Peserta pelatihan secara aktif memainkan perannya masing-masing dalam melakukan interaksi pada situasi yang nyata yang ada di sekitar lingkungannya, dengan menerapkan ilmu pengetahuan yang telah diperoleh atau telah dipelajari sebelumnya.

3. Diskusi pemecahan masalah/studi kasus

Peserta pelatihan diberikan suatu kasus tertentu, lalu secara berkelompok mereka berdiskusi untuk pemecahan masalah, melalui serangkaian proses yang dimulai dengan mendefinisikan masalah, menentukan penyebab utama dari permasalahan, mencari solusi dan alternatif pemecahan masalah, dan mengimplementasikan solusi tersebut sehingga masalah dapat terselesaikan.

4. Latihan praktik

Latihan praktik adalah menerapkan ilmu pengetahuan atau konsep-konsep yang telah dipelajari khususnya praktik pembukuan. 


\section{Materi Pelatihan}

Materi pelatihan terdiri dari:

1. Kewirausahaan;

2. Pemahaman manajemen (organisasi, produksi, keuangan dan pemasaran)

3. Pembuatan rencana bisnis;

4. Pembukuan usaha; Pembuatan proposal pinjaman.

\section{Hasil dan Pembahasan}

Kegiatan pelatihan dilakukan melalui kerjasama dengan Dinas Pariwisata dan Kebudayaan Propinsi Jawa Barat dengan dibantu beberapa narasumber dan praktisi bisnis. Pelatih/nara selain dari ITB, juga dari lembaga perbankan dan praktisi bisnis.

Sebelum pelatihan berlangsung, Dinas Pariwisata dan Kebudayaan Jawa Barat berkoordinasi dengan Dinas Pariwisata dan Kebudayaan Kabupaten Indramayu melakukan seleksi para calon wirausaha di Kabupaten Indramayu yang siap untuk dilatih dan siap membuka usaha. Seleksi dilakukan karena banyaknya peminat yang ingin mengikuti pelatihan, sementara kuota peserta hanya sebanyak 80 orang untuk 2 angkatan. Seleksi meliputi seleksi administrasi dan wawancara menyangkut minat dan keterampilan. Selanjutnya peserta yang lolos seleksi sebanyak 40 orang untuk setiap angkatan, diharuskan melakukan pendaftaran ulang secara on line. Pada hari pelaksanaan pelatihan, peserta yang sudah datang dan mendaftar ditempatkan di hotel/penginapan yang telah disiapkan selama 2 malam. Untuk kelancaran proses pelatihan, para peserta juga diberikan fasilitas berupa training kit.

Hari pertama pelatihan materi yang diberikan meliputi kewirausahaan, pemahaman manajemen (organisasi, produksi, keuangan dan pemasaran), dan pembuatan rencana bisnis. Setelah pembukaan dan sambutan-sambutan, dilakukan pretest dengan tujuan untuk menilai kemampuan/pemahaman awal peserta terhadap materi-materi pelatihan. Penilaian menggunakan instrument pertanyaan terbuka dan tertutup. Hasil pretest disajikan secara bersamaan dengan hasil post test pada Gambar 1.

Pelatihan hari pertama sangat antusisas diikuti para peserta, berlangsung dari jam 8.00 sampai jam 18.00. Materi pelajaran tidak melulu cerita tentang teori tetapi lebih terhadap pembahasan masalah yang mereka hadapi di lapangan. Untuk bidang kewirausahaan semua peserta digabung dalam satu ruangan, materi diberikan diawali dengan ceramah singkat diikuti kemudian simulasi peran dan diakhiri diskusi kelompok pemecahan masalah.

Pada saat materi pemahaman manajemen (organisasi, produksi, keuangan dan pemasaran) dan pembuatan rencana bisnis, peserta dipecah kedalam beberapa ruang kelas kecil, dibagi dalam kelompok pelaku usaha yang memproduksi barang, jasa, serta berdagang. Mereka dapat membahas masalah-masalah yang mereka hadapi selama ini dan memahami cara membuat proposal bisnis sesuai bidang masing-masing. Namun memang perlu lebih dimatangkan kembali di lapangan untuk benar-benar mampu menerapkannya dalam bisnis.

Di hari kedua disampaikan materi pembukuan usaha dan pembuatan proposal pinjaman. Penyampaian materi pembukuan meliputi pengertian, manfaat, dan proses pembukuan, serta bentuk laporan keuangan. Peserta diarahkan untuk bisa membuat laporan keuangan sederhana sebagai bentuk laporan keuangan untuk keperluan evaluasi internal dan eksternal. Metode pelatihan melalui ceramah, diskusi kelompok pemecahan masalah dan latihan praktik secara individu. Antusiasme peserta terlihat dari 
banyaknya pertanyaan yang disampaikan serta riuh ramainya diskusi kelompok untuk mencari solusi terhadap permasalahan kasus yang dihadapi.

Latihan praktik secara individu dalam penyusunan laporan keuangan dimulai dari pencatatan, penggolongan, peringkasan hingga pembuatan laporan keuangan. Dalam pelaksanaan praktik, peserta sangat antusias yang ditunjukkan dengan keseriusan peserta dalam praktik. Dalam hal pembukuan, peserta mampu menyelesaikan kasus praktik penyusunan laporan keuangan dengan baik. Sebagian kecil peserta telah mampu membuat laporan keuangan sederhana seperti laporan laba rugi dan perubahan modal serta arus kas. Namun untuk pembuatan neraca, perlu latihan yang terus menerus mengingat laporan neraca yang dibuat masih belum balance (unbalanced). Sebagian besar lainnya masih mengalami kebingungan, sehingga perlu tindak lanjut pendampingan di tempat usaha pasca pelatihan.

Setelah materi pembukuan selesai dilanjutkan penyampaian materi terakhir yaitu pembuatan rencana bisnis. Pada sesi ini pun tidak kalah menariknya dibanding sesi lainnya, terutama ketika peserta berdiskusi dalam menentukan estimasi rencana bisnis ke masa depan. Sesi akhir di hari kedua adalah post test dan penutupan serta penyampaian kesan dan saran selama pelatihan. Saran yang muncul dari banyak peserta adalah mereka menyarankan untuk mengadakan kegiatan serupa di masa yang akan datang karena sangat bermanfaat bagi mereka.

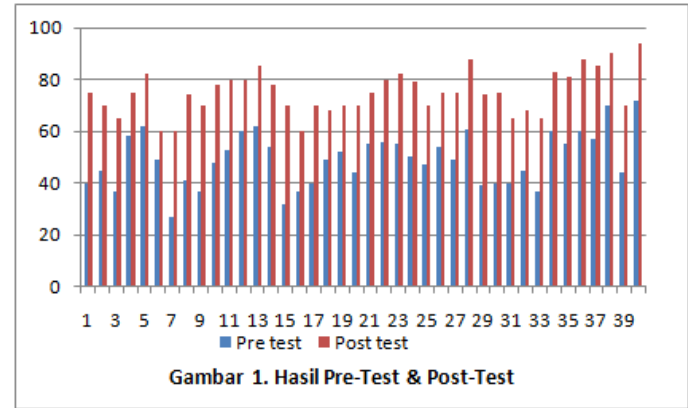

Hasil Pre-test dan Post-test disajikan di Gambar 1, hasilnya seluruh peserta yang berjumlah 40 orang pada angkatan pertama menunjukkan perolehan nilai yang meningkat antara sebelum pelatihan dan setelah pelatihan. Secara keseluruhan rata-rata nilai sebelum pelatihan (pre-test) adalah sebesar 49,3 dan rata-rata nilai setelah pelatihan (post-test) adalah 75,1. Hal ini dapat diartikan bahwa pelatihan ini telah mencapai tujuannya, yaitu adanya peningkatan yang cukup berarti dalam hal pengetahuan, pemahaman dan keterampilan peserta dalam hal kewirausahaan dan pembukuan usaha.

Kondisi pasca pelatihan akan terus dipantau oleh Dinas Pariwisata dan Kebudayaan serta Dinas KUKM Kabupaten Indramayu. Kami sebagai pelatih dalam hal ini, hanya berperan sampai tahap penyelenggaraan pelatihan. Tim dari kantor dinas pemda tersebut akan melakukan tindak lanjut pelatihan dengan melakukan monitoring terhadap keberlanjutan kegiatan ini. Rencana tindak lanjut berisi kegiatankegiatan untuk memperkuat implementasi hasil pelatihan oleh peserta di lapangan. Kegiatannya berupa pembimbingan dan pendampingan terhadap peserta dalam bentuk perencanaan usaha, pembukuan usaha, membangun kerja sama kemitraan usaha, dan pembiayan usaha.

\section{Kesimpulan dan Saran}

Kesimpulan pelaksanaan kegiatan ini adalah: 
1. Kegiatan pelatihan kewirausahaan dan pembukuan sangat diperlukan oleh para calon wirausaha baru, mengingat kebutuhan mereka untuk mendapat pemahaman dan fasilitasi dalam rangka mengatasi permasalahan utama yang dihadapinya di lapangan.

2. Terjadi peningkatan pengetahuan, pemahaman dan keterampilan para peserta antara sebelum pelatihan dengan setelah pelatihan.

3. Disadari pentingnya melakukan pembukuan keuangan usaha sebagai syarat yang penting dalam memperoleh penjaman untuk tambahan modal usaha ke bank dan lembaga keuangan lain.

\section{Saran}

Pelatihan terbatas di ruangan kelas hendaknya dilanjutkan dengan pendampingan di lapangan untuk memastikan apakah para peserta benarbenar bisa menerapkan hal-hal yang telah diperolehnya di pelatihan, dan memberikan solusi langsung terhadap permasalahan yang dihadapi di lapangan yang sesungguhnya.

\section{DAFTAR PUSTAKA}

Claudia, C; H. Prabawati; M. Malihah; M. Novrezi; S. Sahara; D. Safitri. (2019). Pelatihan Pendidikan Karakter pada Anak Pekerja di Yayasan Swara Peduli Indonesia Jakarta. Ethos: Jurnal Penelitian dan Pengabdian kepada Masyarakat, Vol 8, No.1, Juni 2019: 1-8.
Eddie, Davies. (2005). The Art of Training and Development, The Training Manager's a Handbook (terjemahan). P.T. Gramedia : Jakarta.

Heryawan, Ahmad. (2015). Spirit Jabar Lahirkan 100.000 Pengusaha Baru. Selasa, 10 Februari 2015 dalam http://www.investorindonesia.com/e konomidanbisnis/spirit-jabarlahirkan-100000-pengusahabaru/77521, diakses pada 20 Maret 2018.

Malcolm, Tight. (2002). Key Concept in Adult Education and Training 2nd Edition, Routledge Falmer. London.

Oktaviani, V; H. Rahmayanti; F. Fauzan Putra. (2019). Pemberdayaan Masyarakat Desa dalam Mengembangkan Kemandirian Pelaku Industri Kreatif melalui Desain Grafis pada Pendidikan Lingkungan di Bogor. Ethos. Jurnal Penelitian dan Pengabdian kepada Masyarakat, Vol 8, No.1, Juni 2019: 139-144.

Philips, H. Coombs dan Manzoor Ahmed. (1993). Memerangi Kemiskinan di Pedesaan Melalui Pendidikan Nonformal. Publikasi Bank Dunia.

Pio, R. J. (2016). Pemberdayaan Kapasitas Kewirausahaan Kelompok Usaha Kecil. Journal of Business Studies, 2(1), 39-47.

Rivai, V. (2013). Commerical Bank Management: Manajemen Perbankan dan Teori ke Praktik. Edisi 1. Cetakan 1. Jakarta: Rajawali Pers. 